\title{
Rheology and stress in subduction zones around the aseismic/seismic transition
}

\author{
John P. Platt ${ }^{1 *}$, Haoran Xia ${ }^{1,2}$ and William Lamborn Schmidt ${ }^{1}$
}

\begin{abstract}
Subduction channels are commonly occupied by deformed and metamorphosed basaltic rocks, together with clastic and pelagic sediments, which form a zone up to several kilometers thick to depths of at least $40 \mathrm{~km}$. At temperatures above $\sim 350^{\circ} \mathrm{C}$ (corresponding to depths of $>25-35 \mathrm{~km}$ ), the subduction zone undergoes a transition to aseismic behavior, and much of the relative motion is accommodated by ductile deformation in the subduction channel. Microstructures in metagreywacke suggest deformation occurs mainly by solution-redeposition creep in quartz. Interlayered metachert shows evidence for dislocation creep at relatively low stresses (8-13 MPa shear stress). Metachert is likely to be somewhat stronger than metagreywacke, so this value may be an upper limit for the shear stress in the channel as a whole. Metabasaltic rocks deform mainly by transformation-assisted diffusional creep during low-temperature metamorphism and, when dry, are somewhat stronger than metachert. Quartz flow laws for dislocation and solution-redeposition creep suggest strain rates of $\sim 10^{-12} \mathrm{~s}^{-1}$ at $500^{\circ} \mathrm{C}$ and $10 \mathrm{MPa}$ shear stress: this is sufficient to accommodate a $100 \mathrm{~mm} / \mathrm{yr}$. convergence rate within a $1 \mathrm{~km}$ wide ductile shear zone.

The up-dip transition into the seismic zone occurs through a region where deformation is still distributed over a thickness of several kilometers, but occurs by a combination of microfolding, dilational microcracking, and solution-redeposition creep. This process requires a high fluid flux, released by dehydration reactions down-dip, and produces a highly differentiated deformational fabric with alternating millimeter-scale quartz and phyllosilicate-rich bands, and very abundant quartz veins. Bursts of dilational microcracking in zones 100-200 m thick may cause cyclic fluctuations in fluid pressure and may be associated with episodic tremor and slow slip events. Shear stress estimates from dislocation creep microstructures in dynamically recrystallized metachert are $\sim 10 \mathrm{MPa}$.
\end{abstract}

Keywords: Dynamically recrystallized grain size, Dislocation creep, Pressure solution, Tremor, Slow slip

\section{Introduction}

Seismicity along the subduction zone interface at shallow depths transitions downwards into a zone of aseismic creep at depths of 25-40 km (Tichelaar and Ruff 1993). The character and properties of the creeping zone are poorly known: many analyses assume that it is simply a zone of stable slip along the interface (e.g., Holtkamp and Brudzinski 2010), but exhumed rocks from these depths suggest there may be a so-called subduction channel containing metasedimentary and volcanic rocks, which take up much or all of the displacement (Gerya 2002; Warren et al. 2008; Beaumont et al. 2009; Blanco-Quintero et al. 2011; Behr and Platt 2013). The transition between the

\footnotetext{
*Correspondence: jplatt@usc.edu

'Department of Earth Sciences, University of Southern California, Los

Angeles, CA 90089-0740, USA

Full list of author information is available at the end of the article
}

seismic and aseismic zones is particularly interesting, as in a number of subduction zones this is the source of tectonic tremor and slow slip events (Hirose et al. 1999; Dragert et al. 2001; Obara 2002), the origin of which is uncertain (Fig. 1).

Slow slip events involve geodetically determined surface displacements of a few centimeters over periods of a few days to $\sim 1$ year (Peng and Gomberg 2010; Gao et al. 2012); these appear to reflect the release of elastic strain by displacement within the subduction zone at rates that are sub-seismic, but one to two orders of magnitude faster than plate motion rates. Slow slip is commonly accompanied by tremor, a non-impulsive seismic signal that may last for periods up to the duration of the slow slip event (Obara 2002; Rogers and Dragert 2003; Schwartz and Rokosky 2007). Tremor is now thought to be made up of concatenated low-frequency earthquakes (LFEs)-low- 


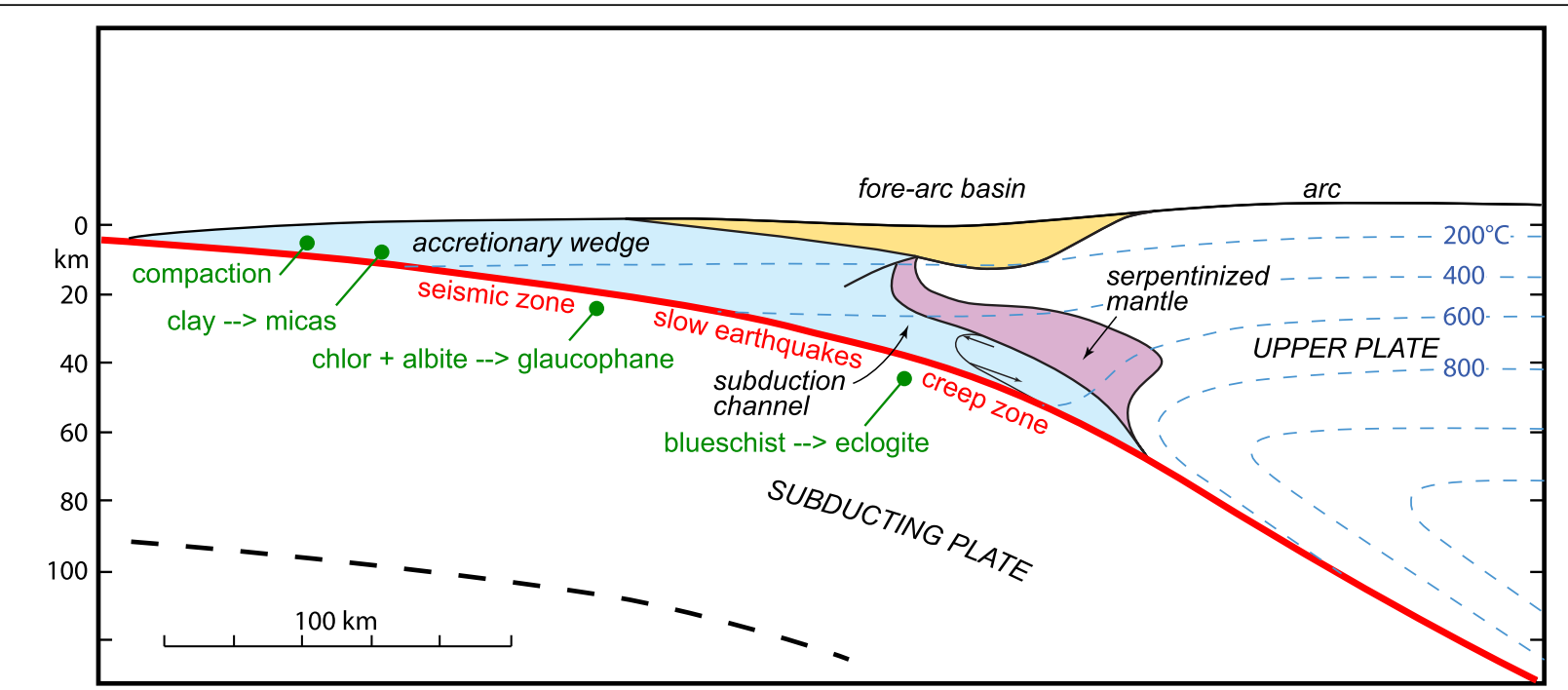

Fig. 1 The seismic-aseismic transition in a subduction zone. Isotherms after Peacock et al. (2011). Slow earthquakes: source region of tectonic tremor and slow slip events. Dehydration processes contributing water to the subduction zone in green. Distribution of serpentinized mantle is schematic

magnitude events with unusually long durations and low frequencies (Shelly et al. 2007; Frank et al. 2016). In this paper, we refer to the spectrum of slow phenomena, such as LFEs, tectonic tremor, and aseismic slow slip events, as slow earthquakes.

Controls on the location of the transition zone remain uncertain. There is general agreement that it does not correspond to a specific temperature (Peacock 2009; Boyarko and Brudzinski 2010), and that pore-fluid pressure is likely to be important (Audet et al. 2009; Peng and Gomberg 2010; Peacock et al. 2011). The seismic-aseismic transition generally occurs in the depth range $25-40 \mathrm{~km}$, corresponding to temperatures in the range $350-500{ }^{\circ} \mathrm{C}$ (Peacock et al. 2011), above the lower temperature limit for crystal plasticity in quartz (Hirth et al. 2001).

A key factor controlling the rheology and response of subduction zones is water. Water is released from hydrated mantle in the subducted plate, the subducted ocean floor, and its sedimentary cover; initially by compaction, and then at progressively increasing depth and temperature by metamorphic dehydration reactions, such as the breakdown of clay minerals to micas and chlorite, chlorite and albite to form glaucophane, serpentine minerals to talc and forsterite (Audet et al. 2009), and blueschist-facies assemblages including sodic amphibole and lawsonite to eclogite-facies assemblages including sodic clinopyroxene (omphacite) and garnet (Peacock et al. 2011). Water can facilitate brittle fracture at depths where the confining pressure would normally inhibit it, by reducing the effective pressure and inducing hydraulic fracture. This process is limited, however, because fracture generally induces dilatancy, which in turn reduces the fluid pressure (Peng and Gomberg 2010); this negative feedback may provide an explanation for slow slip events (Segall et al. 2010). Water also reduces the stress required for crystal plasticity (e.g., Holyoke and Kronenberg 2013) and facilitates metamorphic reactions, producing weak hydrous phases.

Interseismic landward motion recorded by continuous GPS above subduction zones is interpreted as the accumulation of elastic stress that is subsequently released either by true seismic events or by slow earthquakes (Dragert et al. 2001). Slow earthquakes are interpreted by most workers to occur on the plate interface (e.g., Beroza and Ide 2010), and the interpreted focal mechanisms for LFEs are consistent with slip along a gently dipping thrust fault (Ide et al. 2007a, b, Shelly et al. 2007, Frank et al. 2013). Locational uncertainties for LFEs are of the order of $5 \mathrm{~km}$, however (Shelly et al. 2007; Brown et al. 2009; Peng and Gomberg 2010), leaving open the possibility that the sources may not be confined to a single discrete slip surface.

The transition from seismic slip to aseismic creep along the subduction zone is likely to involve a progressive increase in off-fault deformation with depth. The role of this off-fault deformation in accommodating plate convergence at the depth of slow earthquakes is neglected in the above interpretations, and there is an open question as to whether off-fault deformation is responsible for slow earthquakes, or for some component of the interseismic landward motion. The discovery by Ide et al. (2007a, b) of separate moment/ duration scaling relationships for normal seismic events and slow earthquakes suggests a fundamentally different mechanism for slow events. This may involve a component of hydraulic fracture, as suggested by the fact that they occur in a zone characterized by high $\mathrm{Vp} / \mathrm{Vs}$ ratios (e.g., Beroza and Ide 2010), indicating high water content. Tremor and slow slip events have also been attributed to 
fracture of competent rock lenses in otherwise ductile shear zones or melange zones that may be hundreds of meters to kilometers thick (Skarbek et al. 2012; Fagereng et al. 2014; Hayman and Lavier 2014; Behr et al. in press).

The purpose of this paper is to present field and microstructural data from two terranes in California that represent rocks exhumed from the subduction channel developed in the Late Mesozoic to Early Tertiary subduction zone along the western margin of the North American plate. One of these is the Pelona schist in the San Gabriel Mountains of southern California; this is a body of volcanic and sedimentary rocks derived from the underthrust oceanic plate that was metamorphosed at a temperature of $\sim 500{ }^{\circ} \mathrm{C}$ and a depth of $\sim 39 \mathrm{~km}$ during the latest Cretaceous Laramide flat-slab subduction event (Xia and Platt 2017). The other is the South Fork Mountain Schist in the Coast Ranges of northern California, which was metamorphosed at $\sim 350{ }^{\circ} \mathrm{C}$ and a depth of $\sim 30 \mathrm{~km}$ along the subduction zone interface during early Cretaceous subduction (Broecker and Day 1995; Cooper et al. 2011; Schmidt and Platt 2018). The Pelona Schist appears to represent the products of aseismic creep; the conditions under which the South Fork Mountain Schist formed correspond well to the transition zone, hence with a possible source region of slow earthquakes. These two exhumed terrains give us a unique insight into the nature of the seismic-aseismic transition in a subduction zone.

\section{The Pelona Schist: aseismic creep in the subduction zone}

The Pelona Schist in southern California is a body of oceanic metavolcanic and sedimentary rocks exposed in a series of tectonic windows, where it lies beneath Proterozoic crystalline rocks attributed to the North American continent and Mesozoic granitoids belonging to the subduction-related magmatic arc inboard from the trench (Fig. 2). The Pelona Schist is thought to have been thrust beneath the margin during the Laramide flat-slab subduction event (e.g., Jacobson et al. 2007), which truncated the roots of the arc and removed the subcontinental lithosphere, emplacing Laramide oceanic lithosphere and superjacent sedimentary sequences in its place. The situation at the end of the Cretaceous along the western margin of North America at the latitude of California probably closely resembled the present-day subduction zone near Guerrero on the Mexican margin, where flat-slab subduction at $\sim 45 \mathrm{~km}$ depth is on-going at present (Pérez-Campos et al. 2008; Frank et al. 2014).

The Pelona Schist in the San Gabriel Mountains of California is directly overlain by a 500-800 m thick mylonite zone that was originally thought to represent the subduction zone interface. Recent structural and petrological investigations have shown that this ductile shear zone is part of a normal fault system that exhumed

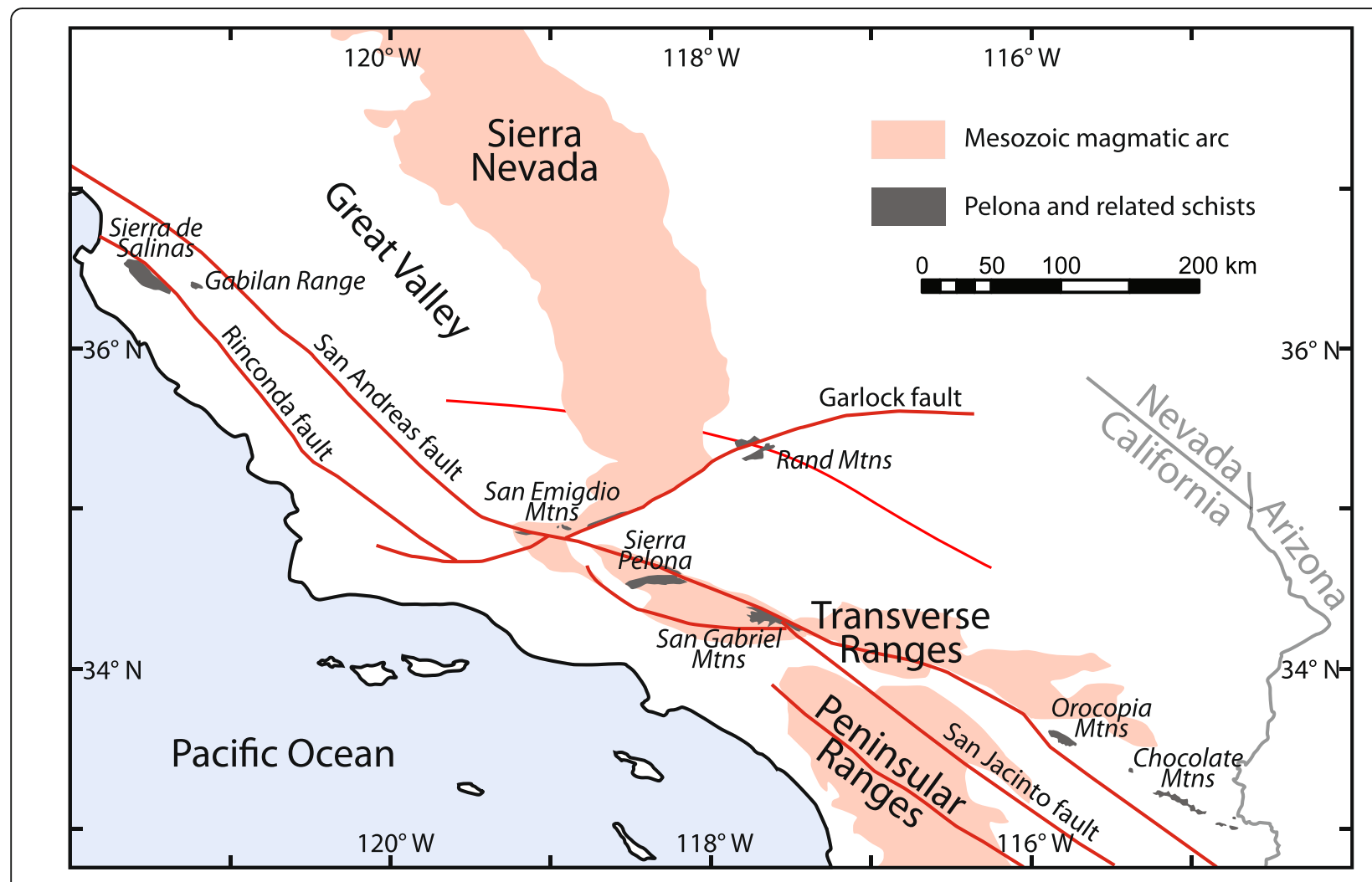

Fig. 2 Pelona Schist and related bodies in southern and central California. Observations presented in this paper are from the San Gabriel mountains 
the Pelona Schist during early Cenozoic time and that the subduction zone interface is no longer preserved (Xia and Platt, in review). The Pelona Schist itself shows a reversal of shear sense over its exposed $\sim 4 \mathrm{~km}$ structural depth. This spatial reversal was established during the early stages of exhumation, associated with retrograde metamorphism immediately after peak temperature and pressure; it is interpreted by Xia and Platt (2017) as indicating that the schist was deformed and exhumed in a subduction channel, probably 5$10 \mathrm{~km}$ thick, the lower part of which is not exposed. Metamorphic conditions during this process were around $500{ }^{\circ} \mathrm{C}$ and $1 \mathrm{GPa}$, consistent with a depth of $39 \mathrm{~km}$ in the subduction zone (Xia and Platt 2017). The Pelona Schist was subsequently exhumed along a major normal fault system, accompanied by mylonitization of both the hanging wall gneisses and granitoids, and the uppermost part of the Pelona Schist itself, under conditions of decreasing pressure and temperature, as is observed for other outcrops of Pelona-type schist (Jacobson et al. 2007).

The bulk of the Pelona Schist consists of metagreywacke, with lesser amounts of metabasaltic rocks (now mafic greenschist) and metachert. Deformation is intense, with complete transposition of bedding and early deformational fabrics into the plane of the dominant foliation, which formed in the subduction channel during exhumation and decompression (Fig. 3a). No discontinuities have been identified associated with this deformation, which was entirely ductile and distributed across at least the $4 \mathrm{~km}$ structural thickness of the schist that is exposed. For this reason, we interpret the deformation in the schist as representing the creeping section of the subduction zone. Deformation in the metagreywacke was accomplished predominantly by pressure solution, which created a differentiated fabric, with laminae rich in sheet silicates (chlorite and white mica) alternating at the millimeter-scale with laminae rich in quartz (Fig. 3b). Rigid porphyroblasts of
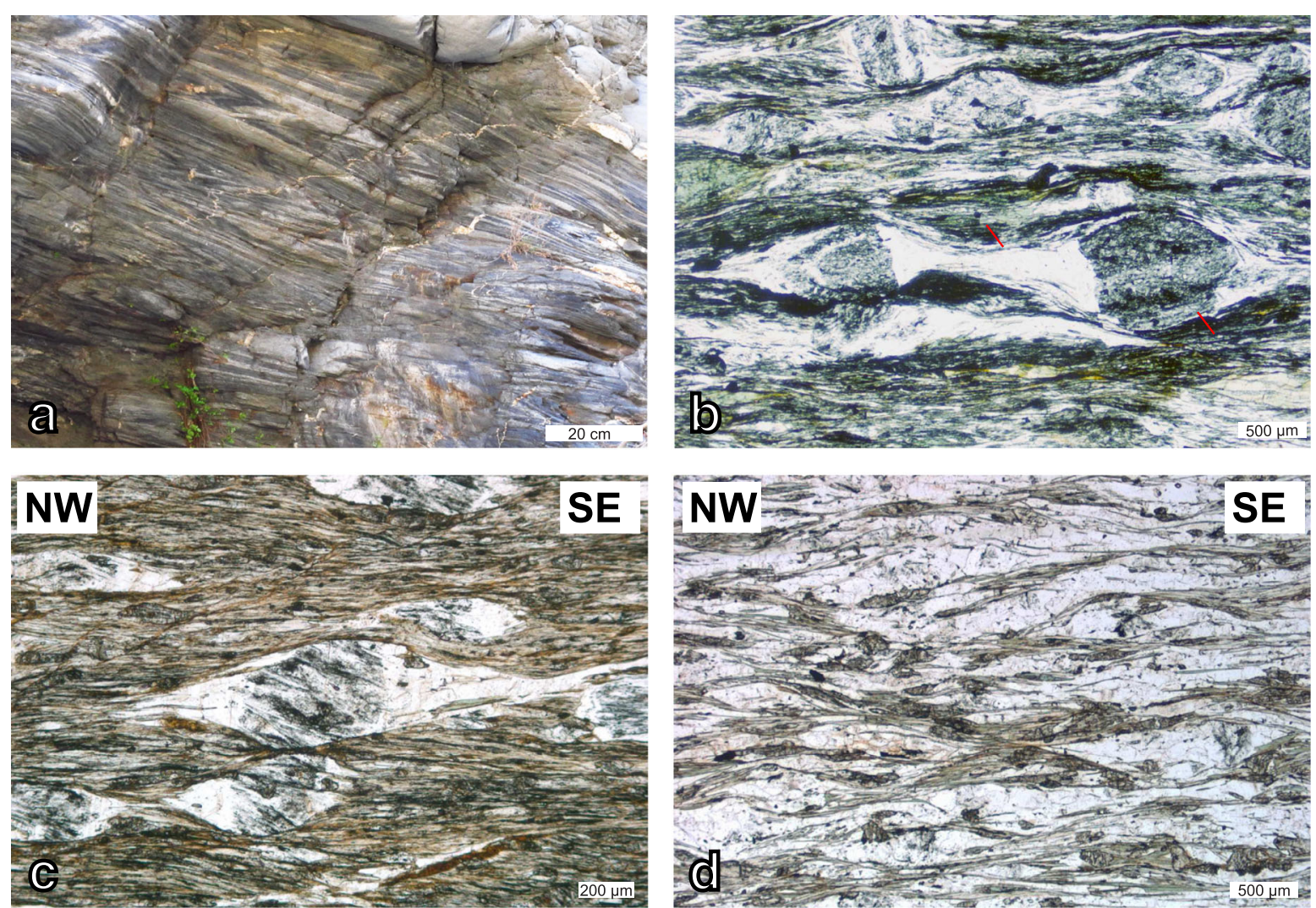

Fig. 3 Structural and microstructural characteristics of the Pelona Schist. a Field photograph of thinly bedded metagreywacke with tight folds formed during return flow. This illustrates the intense ductile deformation characteristic of the schist. b Albite porphyroblasts formed at close to peak metamorphic conditions were pulled apart during return flow, and quartz was precipitated by pressure solution between them. The alternating bands of quartz and sheet silicates (white mica and chlorite) are a characteristic microstructure formed by pressure solution. c Quartz precipitated in pressure shadows around albite porphyroblasts in metagreywacke has an asymmetric shape indicative of top to the left (top NW) shear. The sample comes from the deepest part of the schist, and the microstructures represent the lower part of the subduction channel. $\mathbf{d}$ Asymmetric pressure shadows around albite porphyroblasts from the upper part of the subduction channel have an asymmetry indicating top SE shear sense 


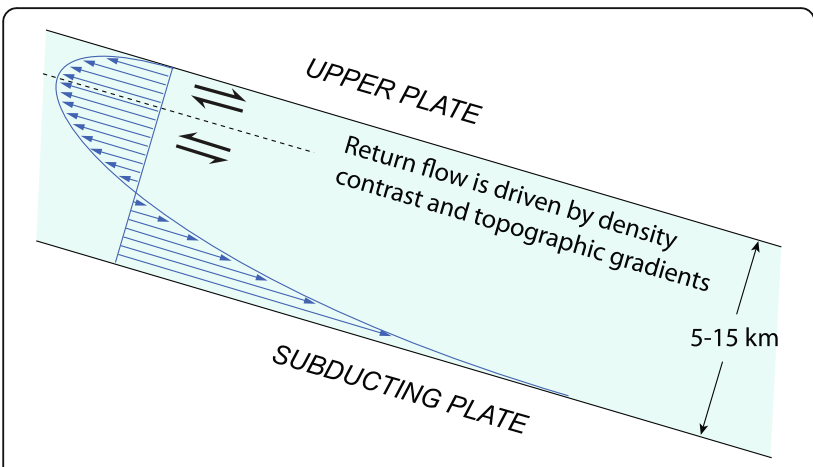

Fig. 4 Pattern of flow in a subduction channel. This is a combination of Couette flow (simple shear) driven by the subducting plate, and Poiseulle flow (channelized flow) driven by a pressure gradient produced by the buoyancy of the subducted sediment and the arctrench topographic gradient. Dashed black line indicates the locus of maximum exhumation rate, across which the sense of shear changes, as shown. Thickness of channel estimated for the Pelona Schist from seismic tomographic data in southern California (Lee et al. 2014)

albite are surrounded by pressure shadows filled with quartz. Inclusion trails within albite define an earlier differentiated fabric that formed during subduction, suggesting that pressure solution was the dominant deformation mechanism throughout the process of subduction and return flow. This is consistent with the widely reported occurrence of pressure solution as the dominant deformation mechanism in many subduction complexes (e.g., Bolhar and Ring 2001; Gratier et al. 2011; Behr and Platt 2013; Wassmann and Stöckhert 2013).
The pressure shadows around albite porphyroblasts are commonly asymmetric and indicate the sense of shear during flow. The sense is top to WNW (in present coordinates) in the lower part of the exposed schist (Fig. 3c) and top to ENE in the top $1000 \mathrm{~m}$ (Fig. 3d). Xia and Platt (2017) interpret this in terms of return flow in a subduction channel $\sim 5-10 \mathrm{~km}$ thick (Fig. 4), which is consistent with the inferred thickness of the Pelona Schist beneath southern California (Lee et al. 2014).

Sparsely distributed metachert within the Pelona Schist shows isoclinal folds and sheath folds, demonstrating that it participated fully in the ductile deformation. The microstructure of the metachert suggests dislocation creep and dynamic recrystallization by the subgrain rotation mechanism (Fig. 5), and this is supported by the presence of a crystallographic preferred orientation of the quartz, with an asymmetric single girdle of c-axes. The dynamically recrystallized grain size in the quartz from metachert on both the ESE- and WNW-directed "limbs" of the return flow system lies in the range $49-85 \mu \mathrm{m}$, which indicates a shear stress during deformation of 8-13 MPa, using the paleopiezometer of Stipp and Tullis (2003), with corrections as suggested by Holyoke and Kronenberg (2010). Differential stress inferred from the piezometer has here been converted to shear stress, appropriate to bulk simple shear flow, by dividing it by $\sqrt{3}$ (Behr and Platt 2013).

The shear stress inferred from the metachert is consistent with dislocation creep (Fig. 6), as is also suggested by the microstructure, but it appears to be inconsistent with the fact that the metagreywackes deformed predominantly
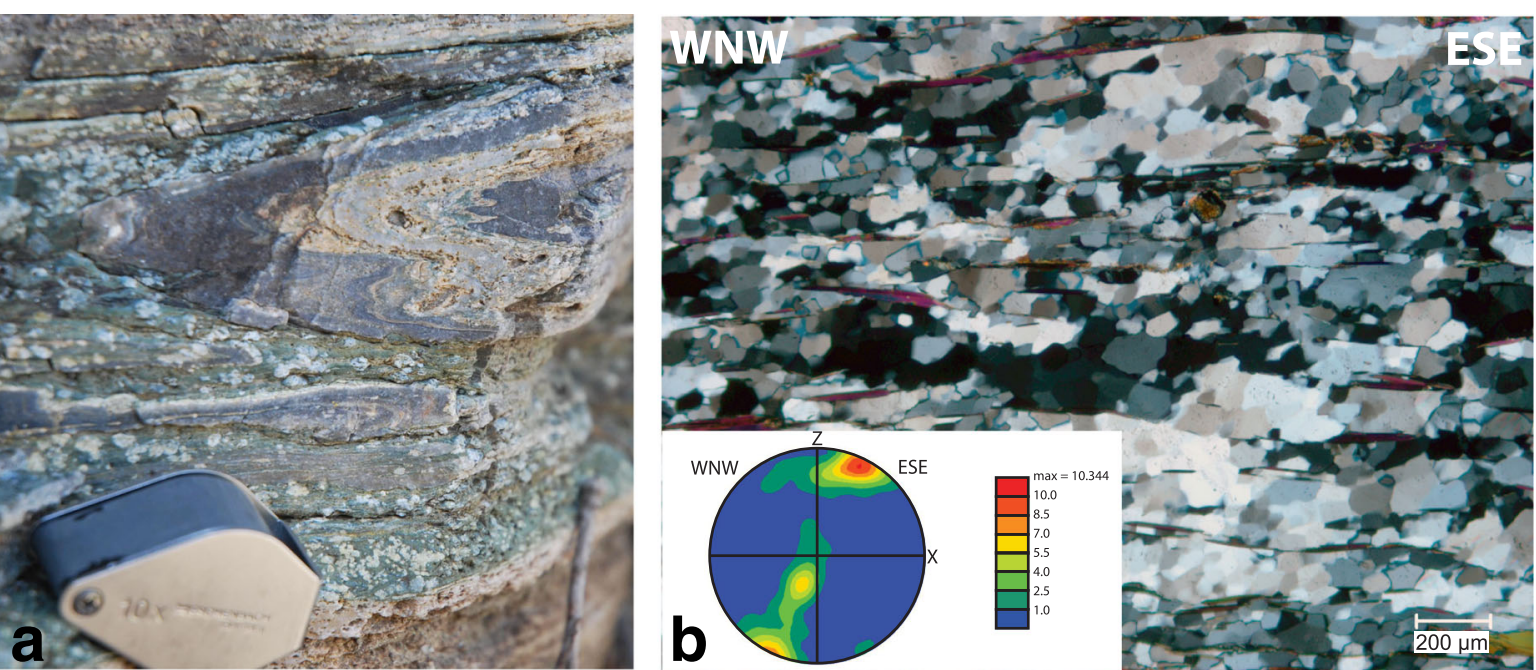

Fig. 5 Paleopiezometry on the Pelona Schist. a Isoclinally folded metachert layer with sheath folds demonstrates that the metachert participates in the same intense ductile deformation as the surrounding metagreywacke. $\mathbf{b}$ The metachert shows microstructural evidence for dislocation creep. Dynamically recrystallized grains define an oblique shape fabric (inclined left), indicating SE shear sense in the upper part of the subduction channel. This is confirmed by the oblique single girdle of quartz c-axes measured by EBSD (inset). X and Z are finite strain axes defined by the macroscopic foliation and lineation. The dynamically recrystallized grain size lies in the range 49-85 $\mu \mathrm{m}$, which corresponds to a shear stress of 8-13 MPa (see text for details) 


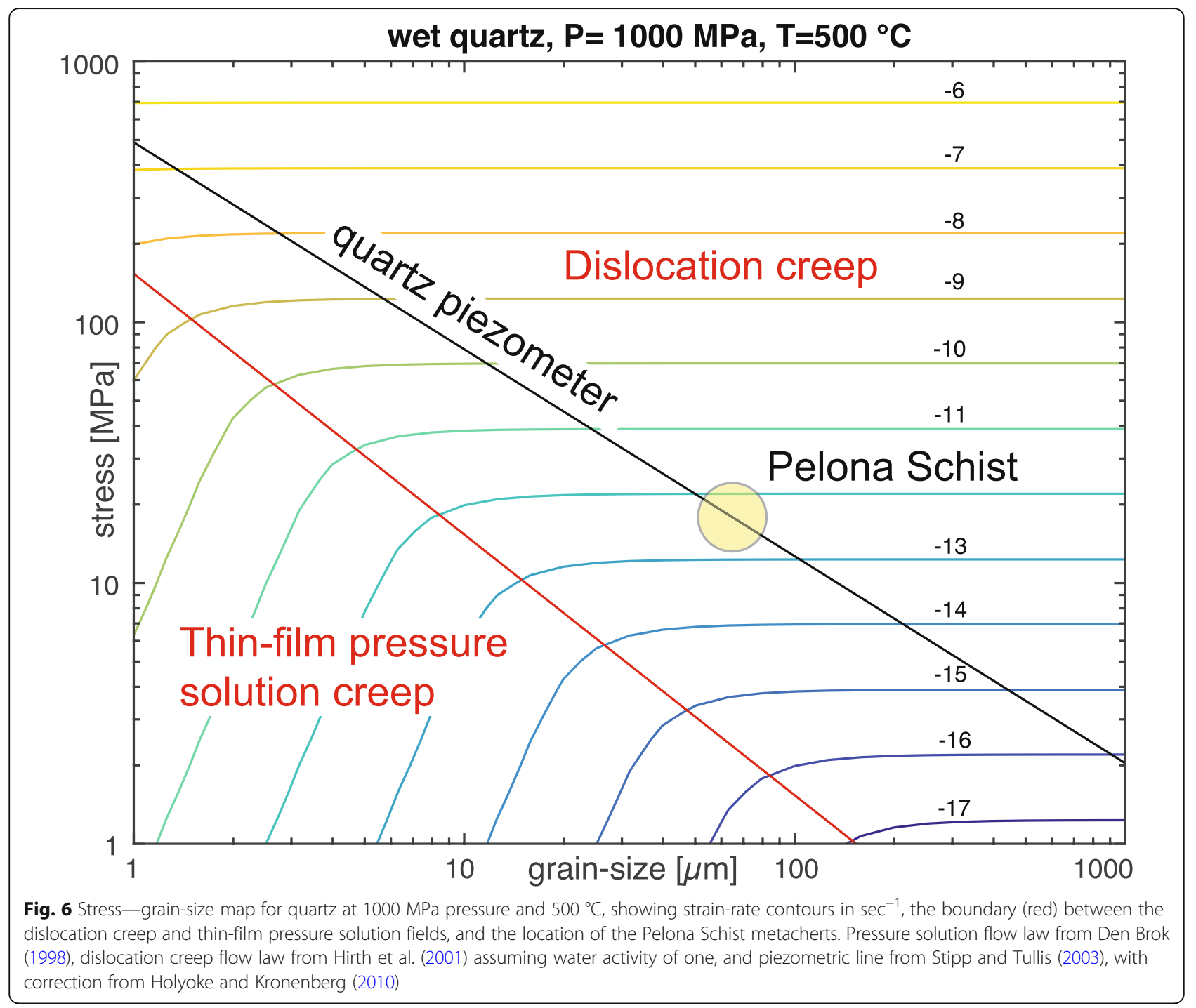

by pressure solution, which in pure quartz would require lower stress or smaller grain size, or both (Fig. 6). Quartz in metagreywacke has recrystallized grain sizes in the range $100-200 \mu \mathrm{m}$, but metachert and metagreywacke appear to have been deformed together to comparable strains, so Xia and Platt (2017) suggest that the rate of pressure solution in the greywacke was enhanced by the presence of abundant sheet silicates, which facilitated the diffusion of aqueous fluids.

Metabasaltic rocks in the Pelona schist were metamorphosed under high-pressure greenschist facies conditions, and contain mineral assemblages dominated by albite, epidote, and Ca-amphibole. During metamorphism these rocks are likely to have deformed by transformationassisted diffusion creep, and may have had very low strength. Once the new mineral assemblage was formed, however, the rock is likely to have been quite strong. Currently available experimental data do not allow us to quantify this, but the field relationships suggest that the rock was at least as strong as the intercalated metachert.

The strain rate in the metachert inferred from the stress and temperature is $\sim 10^{-12} \mathrm{~s}^{-1}$, using the quartz flow law of Hirth et al. (2001). This is sufficient to accommodate a subduction rate of $100 \mathrm{~mm} /$ year, appropriate to the late Cretaceous subduction zone off California, in a zone of simple shear $<1 \mathrm{~km}$ thick. Given that the subduction channel in which the Pelona Schist was deformed was at least $5 \mathrm{~km}$ thick, this appears to justify our assumption that it represents a zone of distributed ductile shear without the need for any discontinuities.

\section{The South Fork Mountain Schist: a possible slow earthquakes source}

The South Fork Mountain Schist (SFMS) is a body of blueschist facies metasedimentary and metavolcanic rocks of oceanic origin that extends for $250 \mathrm{~km}$ along 


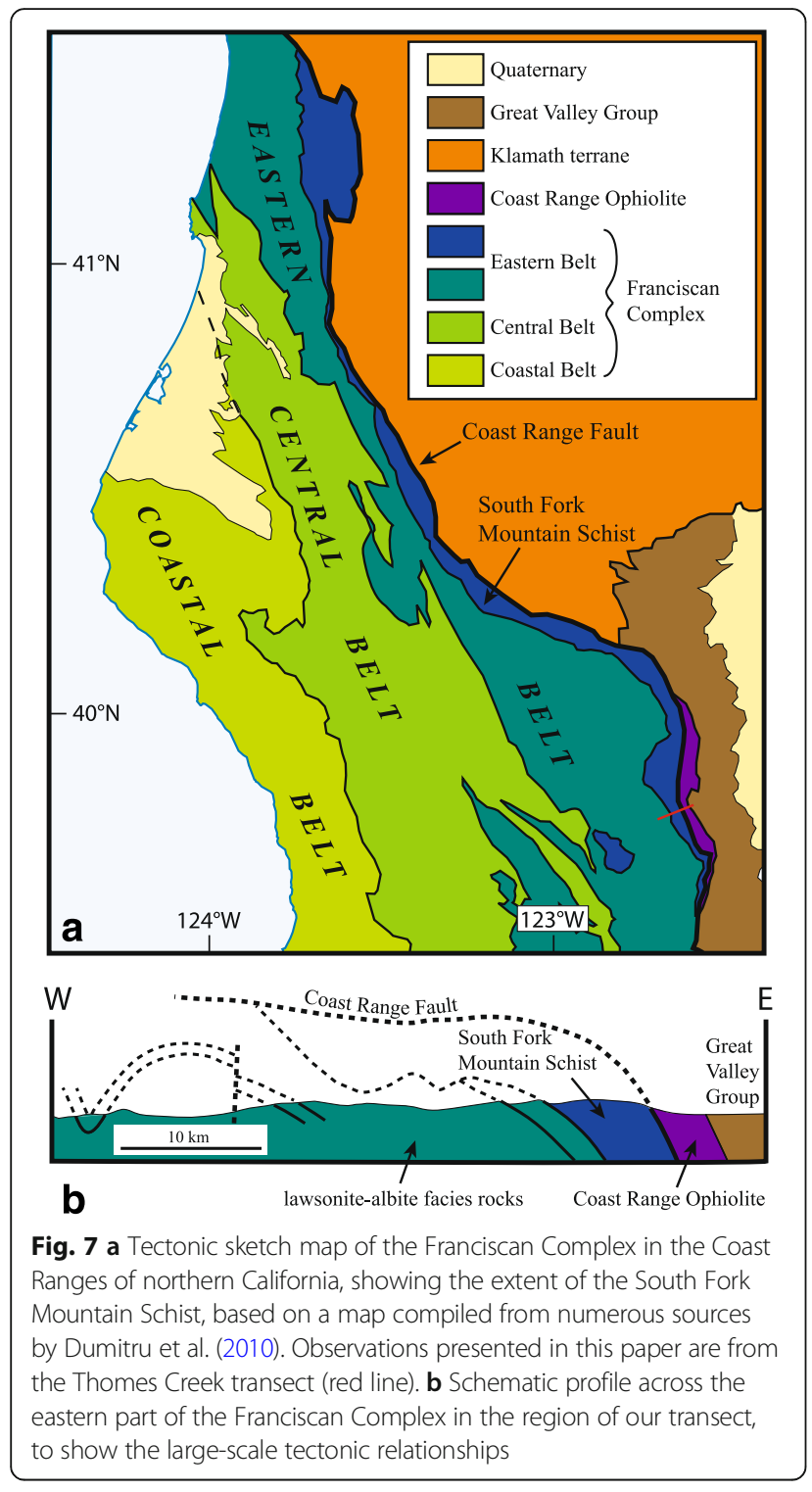

the eastern margin of the Franciscan accretionary complex in northern California (Fig. 7) (Jayko and Blake 1989). Limited detrital zircon ages suggest that the youngest sedimentary components are $\sim 137$ million years old, and Ar-Ar ages on metamorphic mica indicate crystallization or cooling at $\sim 121 \mathrm{Ma}$ (Dumitru et al. 2010), which suggests that the SFMS is the oldest largescale coherent body of metamorphic rock within the Franciscan Complex. This and its structural position immediately beneath the Coast Range ophiolite, which represents the upper plate of the subduction zone, suggest that it formed along the subduction zone interface in Early Cretaceous time (Schmidt and Platt 2018). The unit is $\sim 3.5 \mathrm{~km}$ thick and consists largely of pelitic schist, with subordinate amounts of metabasaltic rocks and metachert.
The SFMS was metamorphosed at around $350{ }^{\circ} \mathrm{C}$ and $800 \mathrm{MPa}$, corresponding to a depth of $\sim 30 \mathrm{~km}$ in the subduction zone (Broecker and Day 1995; Cooper et al. 2011). This places it at a position equivalent to the transition from seismic to aseismic creep on present-day active margins such as the Nankai trough (Peacock 2009) or the Cascadia margin (Peacock et al. 2011), and in a temperature regime similar to that calculated for tremor regions beneath the Kii Peninsula (Peacock 2009). It is intensely deformed, with a strong differentiated fabric composed of alternating millimeter-scale laminae of quartz and sheet silicates, formed by solutionredeposition processes (Schmidt and Platt 2018). This fabric has been redeformed by a predominantly Wvergent set of folds, ranging in scale from millimeterscale crenulations to folds several hundred meters in wavelength. These folds are accompanied by a variably developed axial-planar crenulation cleavage (Fig. 8a, b). A distinctive aspect of these folds is that they were accompanied by dilational microcracking on a range of scales. The most common expression of this is dilational arcs in the hinges of the millimeter-scale crenulations, which were progressively opened by dilational microcracking and then healed by infillings of quartz (Figs. 8c, $\mathrm{d}$ and 9a). Quartz veins also formed on a range of scales at all stages in the deformation history (Fig. 10b). These features form either as hydraulic fractures or as hydraulically assisted shear fractures and indicate fluid pressures approaching lithostatic, at least transiently. Given the low solubility of silica in water at $300{ }^{\circ} \mathrm{C}$, it is likely that these hydraulic fractures opened repeatedly to produce the present-day geometry.

Quartz precipitated in veins and dilational fractures shows microstructural evidence for limited crystal plastic deformation, in the form of subgrains, grainboundary suturing (bulging), and some dynamic recrystallization (Fig. 10b). Plastic deformation alternated with hydraulic fracture, as younger veins show lesser degrees of plastic deformation than older ones (Schmidt and Platt 2018). The size of the dynamically recrystallized grains $(\sim 40 \mu \mathrm{m})$ indicates shear stress of the order of $10 \mathrm{MPa}$, but the evidence for alternating phases of plastic deformation and hydraulic fracture suggests that the shear stress and fluid pressure may have fluctuated repeatedly.

An important aspect of the deformation in the SFMS is that the crenulation trains have the geometry and mechanical characteristics of kink-bands (Fig. 10a). Kink-bands are characteristic of the deformation of strongly anisotropic materials, such as schists (Donath 1968), and they tend to propagate rapidly parallel to the direction of maximum rate of shear strain in the deforming medium (Cobbold et al. 1971; Gay and Weiss 1974). Kinking is greatly facilitated by dilation in the hinge area of the kink, 

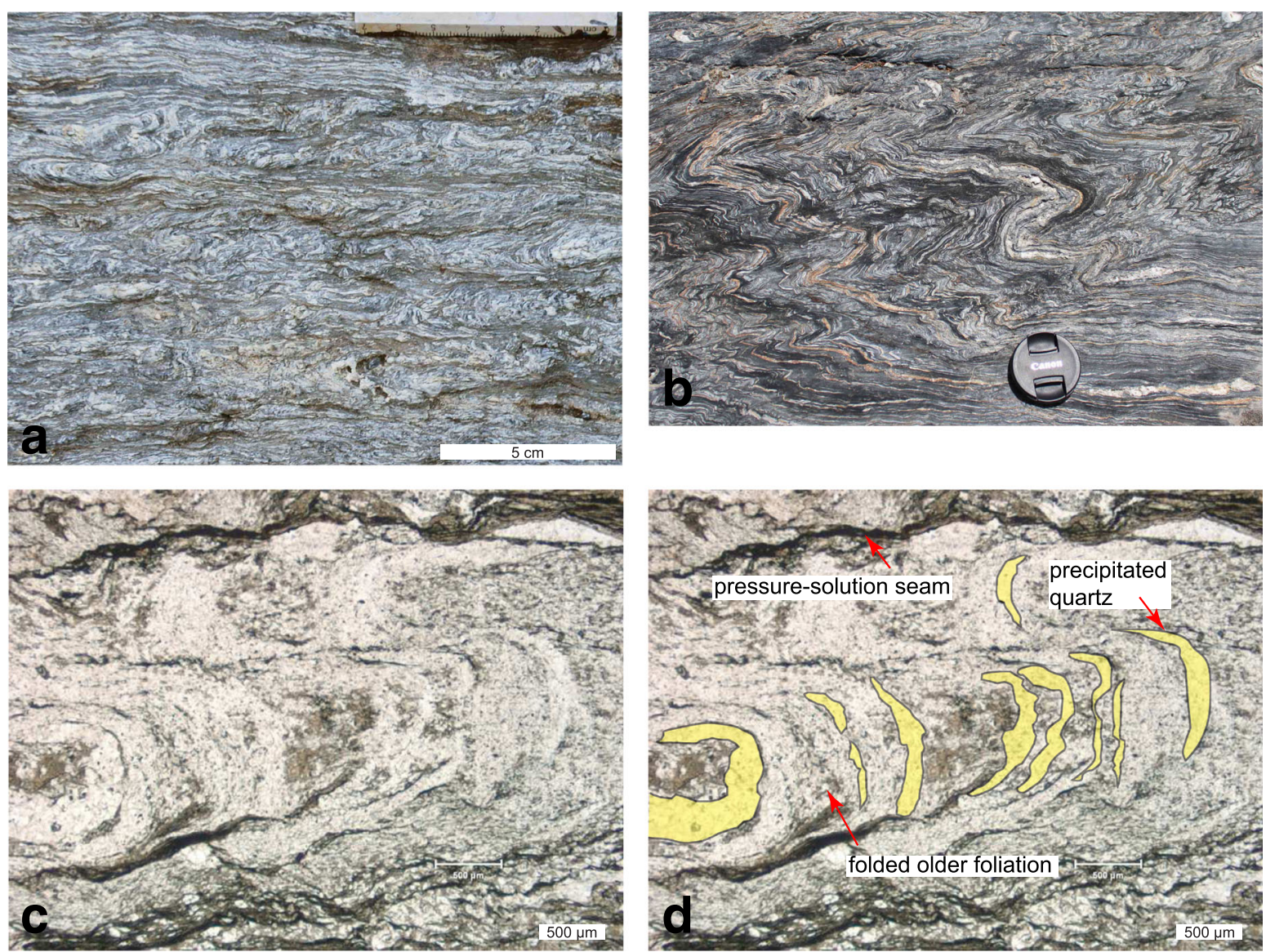

Fig. 8 Structural and microstructural characteristics of the South Fork Mountain Schist. a The dominant foliation in pelitic schist is a transposed crenulation cleavage, formed by microfolding an earlier differentiated fabric, accompanied by pressure solution. b Mesoscopic folds deforming a differentiated fabric, with a new crenulation cleavage forming parallel to the axial planes. c, $\mathbf{d}$ Photomicrograph showing the dilational arcs and pressure-solution seams that form in conjunction with the dominant crenulation cleavage
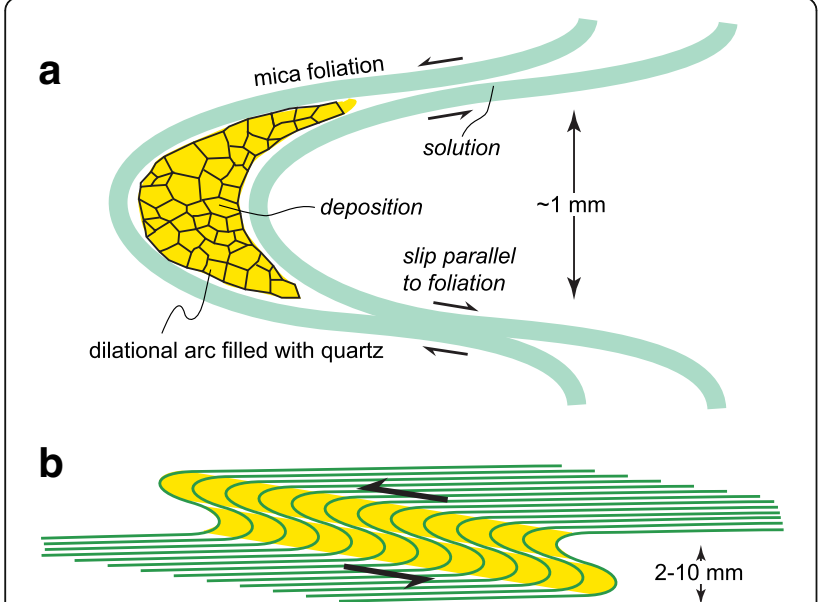

Fig. 9 a Relationship between a microfold (crenulation), the dilational arc in the hinge, and pressure-solution seams along the limbs. b A microfold train is a dilatant shear zone. Incremental growth of these microfold trains can produce displacement and equivalent seismic moment comparable to low-frequency earthquakes as this allows it to develop without components of extension or shortening parallel to the rotating foliation. The crenulations in the SFMS show characteristic dilation in the crenulation arcs, suggesting that high fluid pressure facilitated their formation. The dilational cracks are infilled with quartz, resulting from solution and redeposition of silica during the deformation (Fig. 8). The source of the silica is likely to be the limbs of the crenulations, as these commonly show evidence for pressure solution, such as depletion in quartz and concentration of mica and insoluble materials such as graphite (Schmidt and Platt 2018). A train of these crenulations, such as that illustrated in Fig. 10a, is therefore likely to approximate closely to a zone of simple shear (Fig. 9b), accommodating displacement at a rate that is controlled on short time-scales by hydraulic fracture, and on long time-scales by solution and redeposition of silica.

At $800 \mathrm{MPa}$ pressure and $350{ }^{\circ} \mathrm{C}$, the molar concentration of $\mathrm{SiO}_{2}$ in water is $0.0444 \mathrm{~mol} / \mathrm{kg}$, and the mole fraction is close to $8 \times 10^{-4}$ (Fournier and Potter 1982; den 

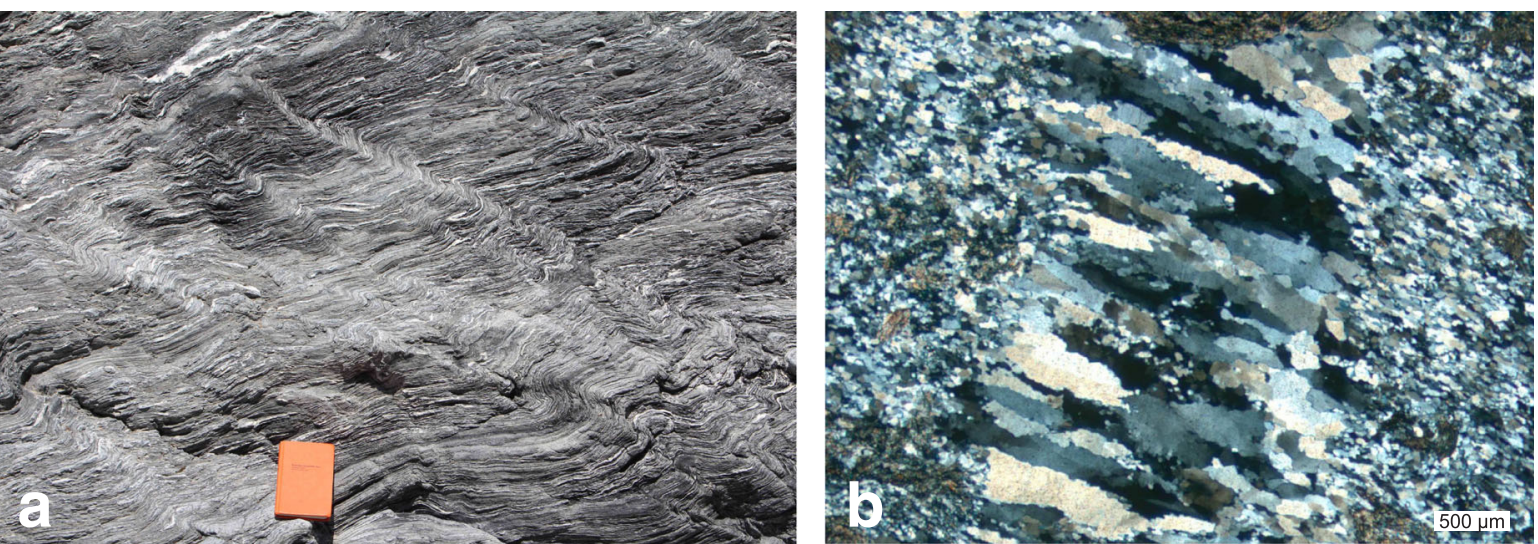

Fig. 10 a Train of crenulations in pelitic schist, showing the kink-like geometry of the microfolds. $\mathbf{b}$ Dynamically recrystallized metachert deformed by dislocation creep, cut by a quartz vein produced by hydraulic fracture. The vein shows cross-fiber geometry, indicating the direction of opening, and grain-boundary bulging and dynamic recrystallization indicating renewed dislocation creep after emplacement

Brok 1998). Hence, a quartz-filled dilation site needs about 1250 times its volume of $\mathrm{SiO}_{2}$-saturated water to pass through it in order to fill it. This could have been achieved by repeated cycles of opening and closing of the void, driven by fluctuations in fluid pressure. Evidence for this type of repeated opening and closing comes from some quartz veins, which show crack-seal type microstructures (Ramsay 1980) indicative of this, but we have not seen evidence for this process in the crenulation arcs. Alternatively, these relatively small voids may have stayed open long enough for sufficient fluid to flow through them to fill them with quartz. Geophysical evidence for largescale fluid flow during slow slip events has been documented by Frank et al. (2015), Skarbek and Rempel (2016) and Taetz et al. (2018).
We postulate that propagation of a train of crenulations is likely to be triggered by high-fluid pressure, rapidly opening up dilational arcs, each of $\sim 1 \mathrm{~mm}$ dimension, in a coordinated fashion to form a shear band with in-plane dimensions of the order of one to a few tens of meters, and an effective shear displacement of $\sim 1 \mathrm{~mm}$ (Fig. 9). The equivalent seismic moment is the slip $\times$ area $\times$ elastic modulus. Assuming a shear modulus of $3 \times 10^{10} \mathrm{~Pa}$, and a linear dimension of $30 \mathrm{~m}$, giving an in-plane area of $10^{3} \mathrm{~m}^{2}$, the equivalent moment is $3 \times 10^{11} \mathrm{~N} \mathrm{~m}$, which is the characteristic size of the LFEs making up tremor bursts (Gao et al. 2012; Frank et al. 2016). The crenulation bands seen in outcrop mostly have linear dimensions of the order of $1 \mathrm{~m}$, but some of them are likely to have extended for

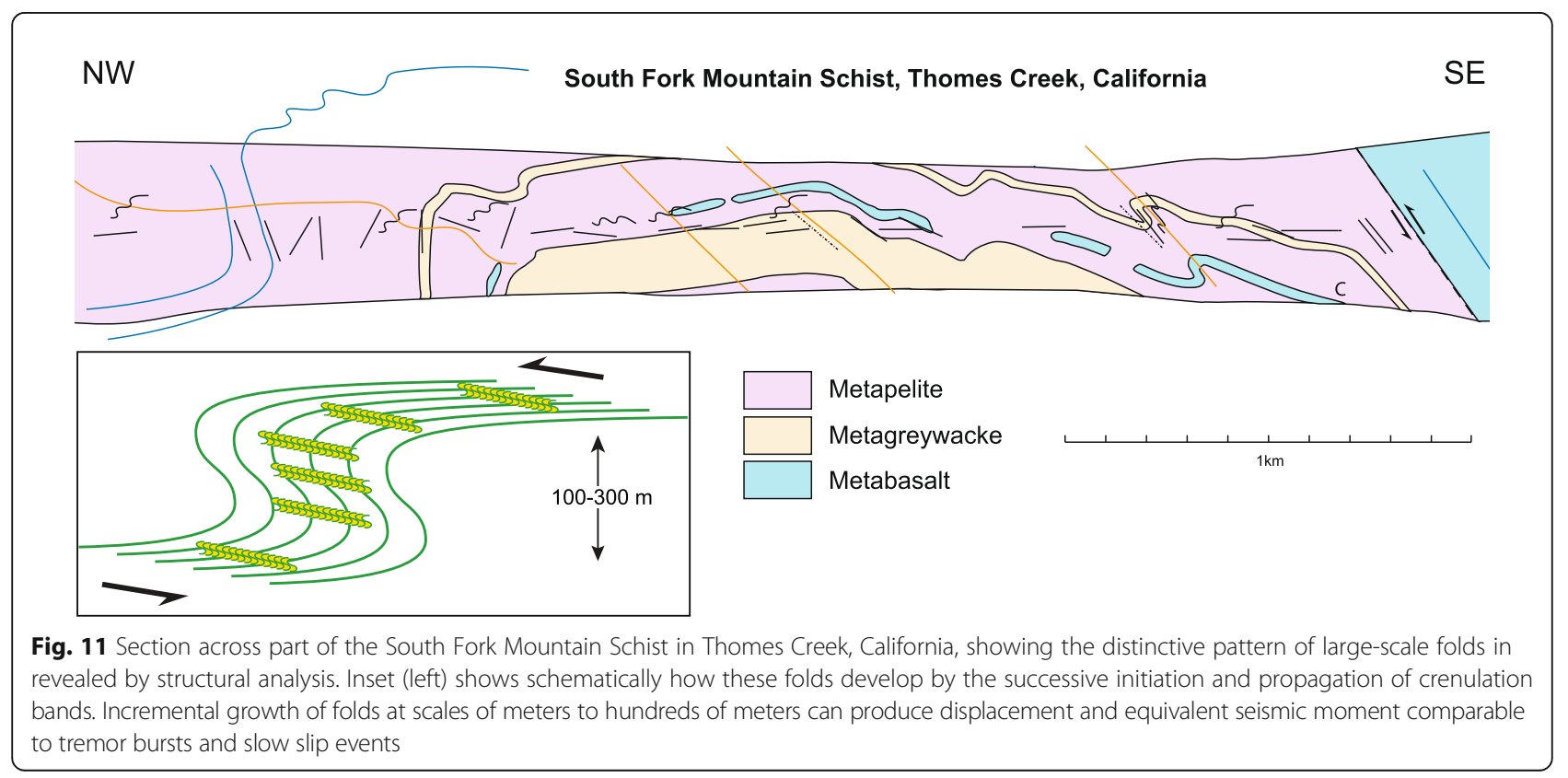




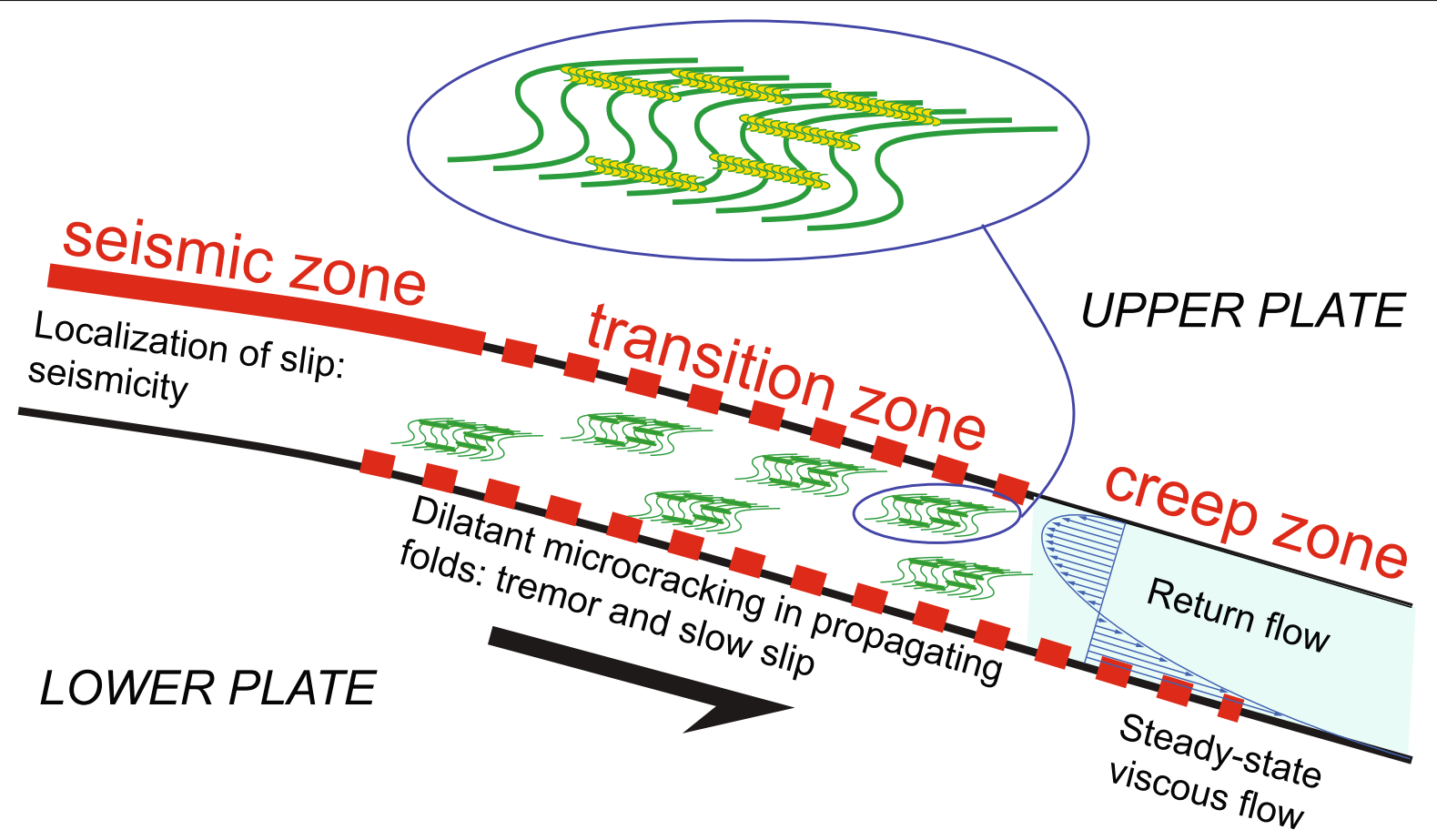

Fig. 12 Relationship between the seismic, transition, and creep zones in a subduction zone, and the processes associated with each. The transition zone is the source of tectonic tremor and slow slip and is also the likely locus of underplating, where the metamorphosed sedimentary and volcanic cover of the subducting plate is progressively accreted to the upper plate. This produces significant off-fault deformation, and the active slip surface migrates downwards. In the creep zone, no discrete displacement surface exists; ductile deformation is distributed in a subduction channel between the two plates. Inset shows folds with axial-planar cleavage of the type shown in Fig. 11; we suggest that the hierarchy of structures at different scales can explain LFEs, tremor bursts, and slow slip events

tens of meters. Given that the cumulative moment release in LFEs is only a small proportion of the total moment release in slow slip events (Peng and Gomberg 2010), we suggest that the largest crenulation bands may be good candidates for LFE sources.

What we cannot determine from the field relationships or the microstructure is the time-scale on which these crenulation bands propagate. The rate-limiting step is the rate at which fluid can permeate from the surrounding rock into the crenulation arcs, which depends on the permeability of the rock and the distance over which the fluid must migrate. At present, we have too few constraints to estimate this.

The formation of these crenulation bands must occur repeatedly to produce the pervasive sets of crenulation cleavages in the SFMS, and the scale of the crenulation arcs is likely to be consistent, as it is controlled by the thickness of the foliation bands making up the earlier fabric that is being crenulated. The process we describe is therefore likely to produce repeating events with very similar characteristics, which is what is observed for LFEs (Shelly et al. 2007; Frank et al. 2014).

The formation of crenulation bands is clearly linked geometrically and mechanically to larger scale folds. These folds were produced by the deformation of strongly layered sandstone-shale sequences, and hence also have the geometry of kink-bands. The folds form a hierarchy of scales, from centimeter scale to hundreds of meters (Schmidt and Platt 2018), controlled by the scale lengths of mechanical layering in the rocks, which varies from individual beds, with thicknesses of centimeters to tens of centimeters, to packages of beds that may have formed in channels or lobes within a submarine fan, with thicknesses ranging from tens of meters to kilometers (Pickering and Hiscott 2016). Buckle folds in deformed sand-shale sequences typically have wavelengths around one order of magnitude larger than the layer thickness, so that scales of folding in any particular sequence will form a hierarchy (Ramberg 1964; Hudleston 1973). Amplification of the larger scale structures is accommodated by the accumulation of displacements on smaller scale structures. This corresponds well to what is observed in slow slip events: LFEs are concatenated to form tremor bursts, with equivalent moments of $\sim 10^{14} \mathrm{~N} \mathrm{~m}$ : these might correspond to the amplification of a meter-scale fold train, with areal dimensions of $10^{5} \mathrm{~m}^{2}$, in which the activity of a series of crenulation bands in a burst leads to a net displacement of $10 \mathrm{~mm}$ (Fig. 8b). Development of folds on scales of 10 $100 \mathrm{~m}$ wavelength and corresponding larger areal dimensions could lead in the same way to displacements 
of tens of centimeters (Fig. 11), corresponding to slow slip events with moment equivalents of up to $5 \times 10^{18} \mathrm{~N} \mathrm{~m}$, which might last for several weeks. Each of these events would involve a concatenated series of amplifications of individual smaller scale folds and crenulation bands, as described above. Initiation of these events would correspond to a peak in fluid pressure, and they would be self-limited by the drop in fluid pressure caused by the opening of the dilational cracks (Segall et al. 2010).

\section{Conclusions}

Field and microstructural observations from the Pelona Schist, an exhumed subduction complex in southern California, suggest that the creeping section of the subduction zone interface, below $30-40 \mathrm{~km}$ depth, is characterized by pervasive ductile flow at a temperature of $\sim 500{ }^{\circ} \mathrm{C}$, including components of shear driven by subduction (Couette flow) and return flow driven by buoyancy and topographic gradients (Poiseuille flow). The predominant deformational mechanism in metagreywacke is thin-film pressure solution, accompanied by dislocation creep in quartz-rich domains including metachert. The dynamically recrystallized grain-size piezometer suggests shear stresses of 8-13 MPa. Inferred strain rates of $10^{-12} \mathrm{~s}^{-1}$ are sufficient to accommodate all the displacement without the need for a discrete slip surface.

At around $30 \mathrm{~km}$ depth and a temperature of $350{ }^{\circ} \mathrm{C}$, there is a transition into zone of seismic slip. The transition zone itself is the source of episodic tremor and slow slip events. Field observations from the South Fork Mountain Schist in the northern California Coast Ranges suggest that this is a zone of distributed deformation $\sim 3.5 \mathrm{~km}$ thick, characterized by intensive microfolding, dilatant fracturing in microfold hinges, and solution-redeposition of quartz, producing multiple differentiated foliations. The dilational microcracks indicate high fluid pressures and fluid content, as is expected in a zone of low seismic velocity and high $\mathrm{Vp} / \mathrm{Vs}$ ratio. Microstructural evidence shows that these processes alternated with dislocation creep, and dynamically recrystallized grain sizes indicate peak shear stresses of the order of $10 \mathrm{MPa}$.

The crenulation trains are kinematically equivalent to shear bands with a reverse shear sense, which can propagate rapidly both up-dip and laterally, and which are capable of producing displacements and seismic moment comparable to low-frequency earthquakes. Because these shear bands accommodate subductiondriven thrust motion, their activity could produce a focal mechanism consistent with that of a gently dipping thrust fault. Development of and amplification of mesoscopic folds by the coordinated development of crenulation trains could be responsible for tremor bursts. The development of larger scale folds with wavelengths of tens to hundreds of meters by the same mechanism could be responsible for slow slip events. The different scales of deformation can therefore be related to the different scales of slow earthquake phenomena. In each case, reasonable estimates of the incremental displacements produced and the equivalent seismic moment are comparable to the observed geophysical phenomena. The distribution of all these processes along the subduction zone interface is summarized in Fig. 12.

\section{Abbreviations \\ LFE: Low-frequency earthquake; SFMS: South Fork Mountain Schist \\ Acknowledgements \\ JPP gratefully acknowledges a travel grant from Japan Geoscience Union to attend the joint JpGU/AGU meeting held in Chiba, Japan. We thank the reviewers for their comments, which helped us to improve the paper; Simon Wallis for editorial handling; and William Frank for assistance with terminology and referencing.}

\section{Funding}

This research was supported in part by NSF grant EAR-1250128 awarded to J.P. Platt.

\section{Authors' contributions}

Work on the Pelona Schist was a PhD project, conceived by JPP, and developed and carried out by HX. Work on the SFMS is an ongoing PhD project, conceived by JPP and being developed and carried out by WLS. Interpretations were developed by all authors in collaboration. All authors read and approved the final manuscript.

\section{Competing interests}

The authors declare that they have no competing interests.

\section{Publisher's Note}

Springer Nature remains neutral with regard to jurisdictional claims in published maps and institutional affiliations.

\section{Author details}

${ }^{1}$ Department of Earth Sciences, University of Southern California, Los Angeles, CA 90089-0740, USA. ${ }^{2}$ Present Address: Chevron Energy Technology Company, 1500 Louisiana St, Houston, TX 77002, USA.

Received: 12 October 2017 Accepted: 10 April 2018

Published online: 27 April 2018

\section{References}

Audet P, Bostock MG, Christensen NI, Peacock SM (2009) Seismic evidence for overpressured subducted oceanic crust and megathrust fault sealing. Nature 457:76-78

Beaumont C, Jamieson RA, Butler JP, Warren CJ (2009) Crustal structure: a key constraint on the mechanism of ultra-high-pressure rock exhumation. Earth Planet Sci Lett 287(1-2):116-129

Behr W, Kotowski A, Ashley K (in press) Dehydration induced rheological heterogeneity and the deep tremor source in subduction zones. Geology

Behr WM, Platt JP (2013) Rheological evolution of a Mediterranean subduction complex. J Struct Geol 54:136-155

Beroza GC, Ide S (2010) Slow earthquakes and nonvolcanic tremor. Annu Rev Earth Planet Sci 39:271-296

Blanco-Quintero I, García-Casco A, Gerya T (2011) Tectonic blocks in serpentinite mélange (eastern Cuba) reveal large-scale convective flow of the subduction channel. Geology 39:79-82

Bolhar R, Ring U (2001) Deformation history of the Yolla Bolly terrane at Leech Lake Mountain, Eastern belt, Franciscan subduction complex, California Coast Ranges. Geol Soc Am Bull 113:181-195 
Boyarko DC, Brudzinski MR (2010) Spatial and temporal patterns of nonvolcanic tremor along the southern Cascadia subduction zone. J Geophys Res Solid Earth 115:B8

Broecker M, Day HW (1995) Low-grade blueschist facies metamorphism of metagreywackes, Franciscan Complex, Northern California. J Metamorph Geol 13:61-78

Brown JR, Beroza GC, Ide S, Ohta K, Shelly DR, Schwartz SY, Rabbel W, Thorwart M, Kao H (2009) Deep low-frequency earthquakes in tremor localize to the plate interface in multiple subduction zones. Geophys Res Lett 36:L19306

Cobbold PR, Cosgrove JW, Summers JM (1971) The development of internal structures in deformed anisotropic rocks. Tectonophysics 12:23-53

Cooper FJ, Platt JP, Anczkiewicz R (2011) Constraints on early Franciscan subduction rates from 2-D thermal modeling. Earth Planet Sci Lett 312(1-2):69-79

den Brok SWJ (1998) Effect of microcracking on pressure-solution strain rate: the Gratz grain boundary model. Geology 26:915-918

Donath FA (1968) Experimental study of kink-band development in strongly anisotropic rock. In: A. J. Ball and D. K. Norris Eds. Conference on Research in Tectonics. Geol Surv Can Pap 68-52:255-288

Dragert H, Wang K, James TS (2001) A silent slip event on the deeper Cascadia subduction interface. Science 292(5521):1525-1528

Dumitru T, Wakabayashi J, Wright JE, Wooden JL (2010) Early cretaceous (ca. 123 $\mathrm{Ma}$ ) transition from nonaccretionary behavior to strongly accretionary behavior within the Franciscan subduction complex. Tectonics 29:TC5001

Fagereng Å, Hillary GWB, Diener JFA (2014) Brittle-viscous deformation, slow slip, and tremor. Geophys Res Lett 41:4159-4167

Fournier RO, Potter RW (1982) An equation correlating the solubility of quartz in water from 25 to $900 \mathrm{C}$ at pressures up to 10,000 bars. Geochim Cosmochim Acta 46(10):1969-1973

Frank WB, Shapiro NM, Husker AL, Kostoglodov V, Bhat HS, Campillo M (2015) Along-fault pore-pressure evolution during a slow-slip event in Guerrero, Mexico. Earth Planet Sci Lett 413:135-143

Frank WB, Shapiro NM, Husker AL, Kostoglodov V, Gusev AA, Campillo M (2016) The evolving interaction of low-frequency earthquakes during transient slip. Sci Adv 2:e1501616

Frank WB, Shapiro NM, Husker AL, Kostoglodov V, Romanenko A, Campillo M (2014) Using systematically characterized low-frequency earthquakes as a fault probe in Guerrero, Mexico. J Geophys Res Solid Earth 119:7686-7700

Frank WB, Shapiro NM, Kostoglodov V, Husker AL, Campillo M, Payero JS, Prieto GA (2013) Low-frequency earthquakes in the Mexican sweet spot. Geophys Res Lett 40:2661-2666

Gao H, Schmidt DA, Weldon RJ (2012) Scaling relationships of source parameters for slow slip events. Bull Seismol Soc Am 102(1):352-360

Gay NC, Weiss LE (1974) The relationship between principal directions and the geometry of kinks in foliated rocks. Tectonophysics 21:287-300

Gerya TV (2002) Exhumation rates of high pressure metamorphic rocks in subduction channels: the effect of rheology. Geophys Res Lett 29(8):102-1-102-4

Gratier JP, Richard J, Renard F, Mittempergher S, Doan ML, Di Toro G, Hadizadeh J, Boullier AM (2011) Aseismic sliding of active faults by pressure solution creep: evidence from the San Andreas Fault Observatory at Depth. Geology 39:1131-1134

Hayman NW, Lavier LL (2014) The geologic record of deep episodic tremor and slip. Geology 42:195-198

Hirose H, Hirahara K, Kimata F, Fujii N, Miyazaki S (1999) A slow thrust slip event following the two 1996 Hyuganada earthquakes beneath the Bungo Channel, southwest Japan. Geophys Res Lett 26:3237-3240

Hirth G, Teyssier C, Dunlap WJ (2001) An evaluation of quartzite flow laws based on comparisons between experimentally and naturally deformed rocks. Int J Earth Sci 90:77-87

Holtkamp S, Brudzinski MR (2010) Determination of slow slip episodes and strain accumulation along the Cascadia margin. J Geophys Res 115:B00A17

Holyoke CW, Kronenberg AK (2010) Accurate differential stress measurement using the molten salt cell and solid salt assemblies in the Griggs apparatus with applications to strength, piezometers and rheology. Tectonophysics 494:17-31

Holyoke CW, Kronenberg AK (2013) Reversible water weakening of quartz. Earth Planet Sci Lett 374:185-190

Hudleston PJ (1973) Fold morphology and some geometrical implications of theories of fold development. Tectonophysics 16:1-46

Ide S, Beroza C, Shelly DR, Uchide T (2007a) A scaling law for slow earthquakes. Nature 447:76-79
Ide S, Shelly DR, Beroza GC (2007b) Mechanism of deep low frequency earthquakes: further evidence that deep non-volcanic tremor is generated by shear slip on the plate interface. Geophys Res Lett 34:2191-2195

Jacobson C, Grove M, Vucic A, Pedrick J, Cloos M, Carlson W, Gilbert M, Liou J, Sorensen S (2007) Exhumation of the Orocopia Schist and associated rocks of southeastern California: relative roles of erosion, synsubduction tectonic denudation, and middle Cenozoic extension, pp 1-37

Jayko AS, Blake MC (1989) Deformation of the Eastern Franciscan Belt, northern California. J Struct Geol 11: 375-390

Lee E-J, Chen P, Jordan TH, Maechling PB, Denolle MA, Beroza GC (2014) Full-3-D tomography for crustal structure in Southern California based on the scattering-integral and the adjoint-wavefield methods. J Geophys Res Solid Earth 119:6421-6451

Obara K (2002) Nonvolcanic deep tremor associated with subduction in southwest Japan. Science 296(5573):1679-1681

Peacock SM (2009) Thermal and metamorphic environment of subduction zone episodic tremor and slip. J Geophys Res Solid Earth 114:B8

Peacock SM, Christensen NI, Bostock MG, Audet P (2011) High pore pressures and porosity at $35 \mathrm{~km}$ depth in the Cascadia subduction zone. Geology 39: 471-474

Peng Z, Gomberg J (2010) An integrated perspective of the continuum between earthquakes and slow-slip phenomena. Nat Geosci 3:599-607

Pérez-Campos X, Kim Y, Husker A, Davis PM, Clayton RW, Iglesias A, Pacheco JF, Singh SK, Manea VC, Gurnis M (2008) Horizontal subduction and truncation of the Cocos Plate beneath central Mexico. Geophys Res Lett 35:L18303

Pickering KT, Hiscott RN (2016) Deep marine systems: processes, deposits, environments, tectonics and sedimentation. Wiley, Oxford, $657 \mathrm{pp}$.

Ramberg H (1964) Selective buckling of composite layers with contrasted physical properties : a theory for simultaneous formation of several orders of folds. Tectonophysics 1:307

Ramsay JG (1980) The crack-seal mechanism of rock deformation. Nature 284:135-139

Rogers G, Dragert H (2003) Episodic tremor and slip on the Cascadia subduction zone: the chatter of silent slip. Science 300(5627):1942-1943

Schmidt, W. L., and J. P. Platt (2018), Subduction, accretion, and exhumation of coherent Franciscan blueschist-facies rocks, northern coast ranges, California, Lithosphere

Schwartz SY, Rokosky JM (2007) Slow slip events and seismic tremor at circumPacific subduction zones. Rev Geophys 45(3):RG3004

Segall P, Rubin AM, Bradley AM, Rice JR (2010) Dilatant strengthening as a mechanism for slow slip events. J Geophys Res 115:B12305

Shelly DR, Beroza GC, Ide S (2007) Non-volcanic tremor and low-frequency earthquake swarms. Nature 446:305-307

Skarbek RM, Rempel AW (2016) Dehydration induced porosity waves and episodic tremor and slip. Geochem Geophys Geosyst 17:442-469

Skarbek RM, Rempel AW, Schmidt DA (2012) Geologic heterogeneity can produce aseismic slip transients. Geophys Res Lett 39, L21306

Stipp M, Tullis J (2003) The recrystallized grain size piezometer for quartz. Geophys Res Lett 30:2088 3-1 - 3-5

Taetz S, John T, Bröcker M, Spandler C, Stracke A (2018) Fast intraslab fluid-flow events linked to pulses of high pore fluid pressure at the subducted plate interface. Earth Planet Sci Lett 482:33-43

Tichelaar BW, Ruff $\amalg$ (1993) Depth of seismic coupling along subduction zones. J Geophys Res 98(B2):2017-2037

Warren C, Beaumont C, Jamieson RA (2008) Deep subduction and exhumation: role of crustal strength and strain weakening in continental subduction and ultrahigh-pressure rock exhumation. Tectonics 27:TC6002

Wassmann S, Stöckhert B (2013) Rheology of the plate interface-dissolution precipitation creep in high pressure metamorphic rocks. Tectonophysics 608:1-29

Xia H, Platt JP (2017) Structural and rheological evolution of the Laramide subduction channel in southern California. Solid Earth 8:379-403 